\title{
MONITORING EVAPORITE KARST ACTIVITY AND LAND SUBSIDENCE IN THE HOLBROOK BASIN, ARIZONA USING INTERFEROMETRIC SYNTHETIC APERTURE RADAR (INSAR)
}

\author{
Brian D. Conway \\ Arizona Department of Water Resources, 3550 N.Central Ave, Phoenix, AZ 85012 USA, bdconway@azwater.gov \\ Joseph P. Cook \\ Arizona Geological Survey, 416 W. Congress St, Suite 100,Tucson, AZ 85701 USA, joe.cook@azgs.az.gov
}

\begin{abstract}
The Holbrook Basin located in east-central Arizona is home to more than 500 evaporite-karst depressions. The Arizona Department of Water Resources (ADWR) recently acquired, processed, and interpreted archived Interferometric Synthetic Aperture Radar (InSAR) data to evaluate historical deformation patterns in the Holbrook Basin in preparation for monitoring potential future subsidence related to planned potash mining activities around the Petrified Forest National Park. Three active land subsidence features were identified by ADWR using InSAR data from the European Space Agency's ERS 1 and 2 satellites between 1992 and 1997. Continued subsidence in two of the three features was also identified by ADWR using InSAR data from the Japan Aerospace Exploration Agency's ALOS satellite collected from 2006 to 2011.
\end{abstract}

In June 2012 Arizona Geological Survey (AZGS) and ADWR staff visited one of the more prominent subsidence features identified using InSAR. Numerous steep-walled evaporite-karst sinkholes were observed en route to the field site. These roughly circular collapse features ranged in size from 40-130 $\mathrm{m}$ across and 10$30 \mathrm{~m}$ deep. The subsidence features identified through InSAR are much more extensive, up to $1,100 \mathrm{~m}$ across; are not as deep, up to $15 \mathrm{~m}$; and do not have steep walls. Local subsidence has resulted in broad closed basins with drainage reversals and numerous expanded joints in the Coconino Sandstone exposed at the surface. A thin sandy soil above the Coconino covers the basin floor except where collapsed into open joints. Expansion along both joint orientations was observed. Which orientation was expanded depended on location relative to ongoing subsidence. Based on field observations and comparison with other collapse features in the region, these three subsidence features are relatively young, constitute different collapse morphology than nearby sinkholes, and warrant further study. InSAR will remain a critical remote-sensing tool for monitoring land subsidence in the Holbrook Basin.

\section{Introduction}

The Holbrook salt basin is located in east-central Arizona and is predominantly composed of halite with lesser amounts of anhydrite, gypsum and sylvite interbedded with dolomite, sand, and shale in the Corduroy Member of the Schnebly Hill Formation of the Permian Sedona Group (Peirce and Gerrard, 1966). The Holbrook salt body underlies more than $9,000 \mathrm{~km}^{2}$ of eastern Arizona between the towns of Winslow, Sanders, Springerville, and Heber. The study area for this report lies southwest of Holbrook and covers approximately $50 \mathrm{~km}^{2}$ (Figure 1). Salt up to $200 \mathrm{~m}$ thick has been measured south of the Petrified Forest National Park boundary southeast of Holbrook (Rauzi, 2000). This portion of the Holbrook salt body has become the focus of much interest from investors and mining companies due to the presence of up to 2.5 billion metric tons of potash (sylvite) near the top of the evaporite deposits. Due to the potential for land subsidence related to possible future potash mining, ADWR has begun collecting InSAR data for the region surrounding the limits of the potash deposit. Through evaluation of InSAR interferograms it was determined some areas overlying the Holbrook salt body are actively subsiding today or have been in the last 20 years.

\section{Geologic Setting}

The evaporite beds of the Holbrook salt body lie within the upper Sedona Group (Supai elsewhere) and are overlain by Permian Coconino Sandstone, Kaibab Limestone, and fine grained beds of the Triassic Moenkopi Formation. Coconino Sandstone is the most laterally extensive exposed bedrock at the surface throughout the study 


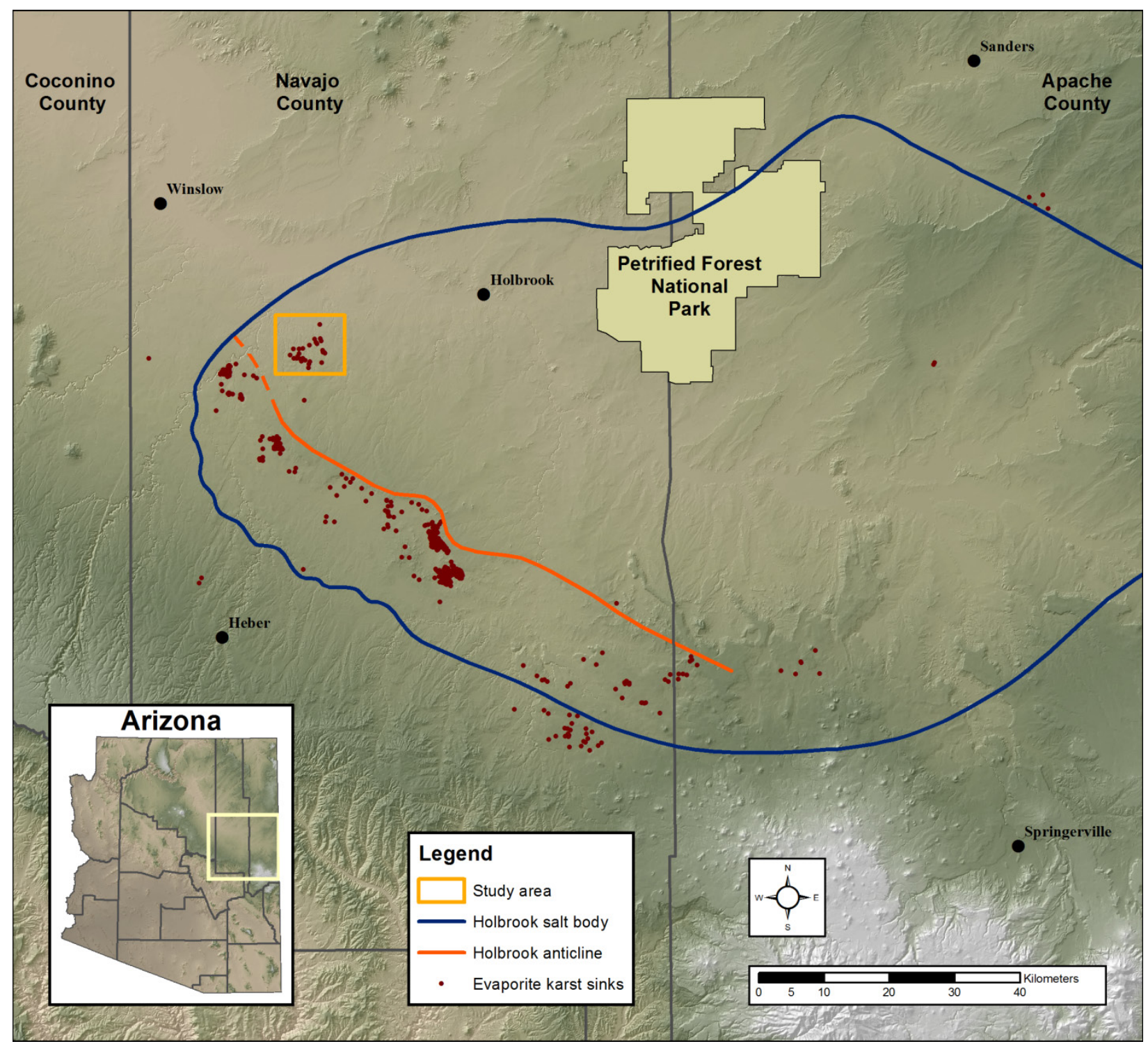

Figure 1. Location map of Holbrook Basin, study area extent, and distribution of existing evaporite karst sinks relative to the extent of the Holbrook salt body and anticline.

area. Thin beds of Kaibab Limestone are present near the western boundary of the salt body, but pinch out to the east. Isolated thin exposures of red Moenkopi sands mantle the lighter tan, distinctly crossbedded Coconino Sandstone elsewhere.

Dissolution of salt at depth in the Holbrook Basin has resulted in more than 500 sinkholes, expanded bedrock joints and joint sets, compression ridges and buckles, and numerous subsidence-related geomorphic changes including drainage captures and reversals. The vast majority of sinkhole development is located along the trend of the Holbrook anticline near the southwest margin of the salt body (Figure
1, Neal et al., 1998), but isolated depressions do exist in undeformed beds above evaporite deposits to the northeast. Many of the depressions along the anticline are circular and steep-sided, up to $130 \mathrm{~m}$ across and $30 \mathrm{~m}$ deep. Depressions located farther from the dissolution flexure are often much more extensive and not as deep, up to $3 \mathrm{~km}$ across and 15 $\mathrm{m}$ deep. Dissolution of Permian salt and associated subsidence of overlying rock layers in the Holbrook Basin has likely been occurring since the Pliocene (Neal et al., 1998). Using modern remote sensing techniques such as InSAR, land-surface change monitoring, it is possible to determine whether subsidence is ongoing in the Holbrook Basin today. 


\section{Land Subsidence Monitoring using InSAR}

ADWR has been collecting, processing, and analyzing InSAR data for monitoring land subsidence throughout Arizona since 2002. ADWR's InSAR program has produced invaluable results and end products that are used not only by ADWR but also other state, county, and local agencies, universities, and private companies for their own monitoring, modeling, mitigation, planning and design projects.

Synthetic Aperture Radar (SAR) is a side-looking, active (produces its own illumination) radar-imaging system that transmits a pulsed microwave signal towards the earth and records both the amplitude and phase of the back-scattered signal that returns to the antenna. InSAR is a technique that utilizes interferometric processing that compares the amplitude and phase signals received during successive passes of the SAR platform over a specific geographic area at different times. InSAR techniques, using satellite-based SAR platform data, can be used to produce land- surface deformation products with $\mathrm{cm}$ scale vertical resolution. Changes in land elevation are detected through the change in phase of the radar signal. InSAR is used to detect surface motion along active faults, on volcanoes, landslides, sinkholes, and other geologic hazards (Galloway and Hoffmann, 2007).

ADWR has compiled an extensive historical InSAR dataset for the active land subsidence areas identified with InSAR in Arizona. Most data sets cover time periods between 1992 to 2000, 2004 to 2010, 2006 to 2011, and 2010 to present. ADWR has identified more than 25 land subsidence features in Arizona, collectively covering more than $3,600 \mathrm{~km}^{2}$.

ADWR has used InSAR not only for monitoring land subsidence but also seasonal deformation (uplift and subsidence), natural and artificial recharge events, as a tool for geological mapping and investigations, locating earth fissures, identifying areas where conditions may exist for future earth fissure formation, and for dam mitigation and land subsidence modeling.

\section{InSAR Results}

ADWR collected InSAR data from the Alaska Satellite Facility (ASF) and the Japanese Aerospace Exploration Agency's (JAXA) L-Band Advance Land Observing Satellite (ALOS-1) satellite for the Holbrook Basin in northeastern Arizona. The InSAR data were collected to evaluate land subsidence associated with any of the existing evaporite-karst sinkholes and to develop a baseline for possible future land subsidence related to proposed potash mining near the Petrified Forest National Park.

Six satellite passes of the ALOS-1 path 201 frame 280 SAR data were downloaded from the ASF which allowed ADWR to create fifteen different interferograms. Two new land subsidence features were identified using the ALOS-1 InSAR data (Figure 2).

Land subsidence measured with the ALOS-1 InSAR data from 12/06/2006 to 02/01/2011 in the western and eastern sink was as high as $5 \mathrm{~cm}$ and $26 \mathrm{~cm}$, respectively. This interferogram covering 4.15 years was the longest timespan available to be processed for the ALOS-1 InSAR pairs. The spatial extent and magnitude of land subsidence of the new land subsidence features was consistent across all the other interferograms.

To better understand the historical activity of the new land subsidence features, ADWR ordered archived SAR data for the European Space Agency's (ESA) European Remote Sensing-1 and 2 (ERS-1 and ERS-2) satellites.

A total of 28 satellite passes of ERS-1 and ERS-2 track 456 were downloaded from ESA which allowed ADWR to create 27 interferograms. The historical dataset from 1992 to 1997 identified the same two land subsidence features identified in ALOS- 1 dataset. The ERS- 1 and ERS-2 dataset also identified a third new subsidence feature

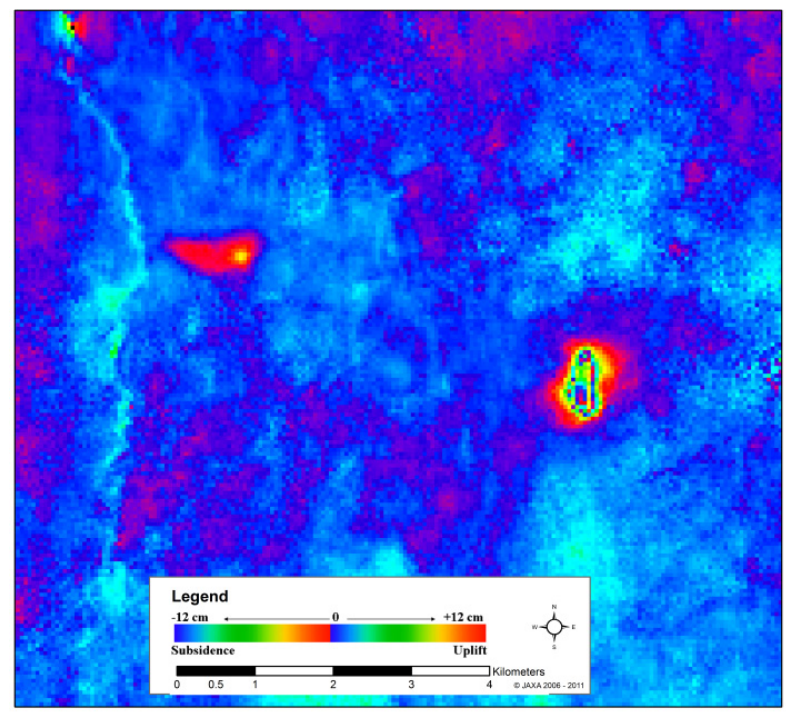

Figure 2. ALOS- 1 12/06/2006 to 02/01/201 1 Interferogram. 


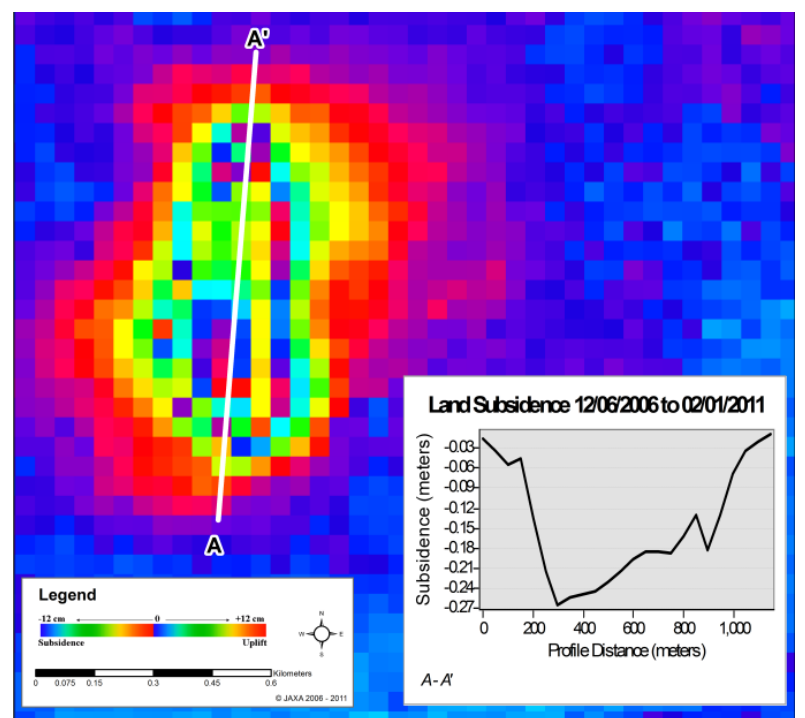

Figure 3. Eastern Land Subsidence Sink and InSAR Profile.

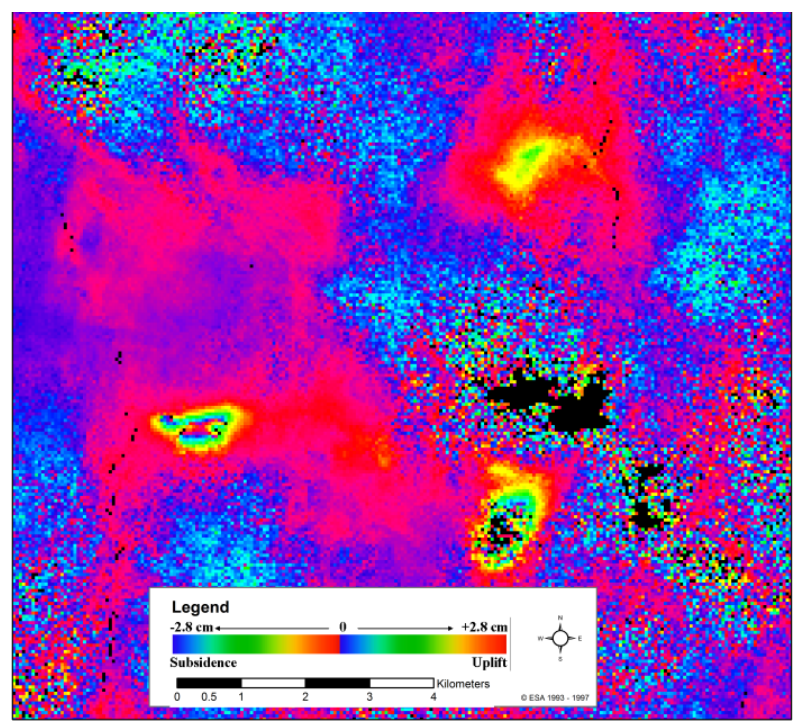

Figure 4. ERS- $1 / 211 / 24 / 1992$ to 03/07/1997 Interferogram.

located approximately $5 \mathrm{~km}$ north of the eastern feature. This feature was not observed in the more recent ALOS-1 dataset (Figure 2).

The reasons why the northern land subsidence feature is apparent in the 1992-1997 interferogram, but absent in later years (2006-2011) are unknown. It is possible subsidence at the northern feature is episodic or complete. Land subsidence as high as $2.7 \mathrm{~cm}, 3.5 \mathrm{~cm}$, and $1.7 \mathrm{~cm}$ was measured with the ERS- 1 and ERS-2 InSAR data in the western, eastern, and northern subsidence features, respectively. Continued InSAR monitoring of this area will help constrain subsidence rates and patterns.

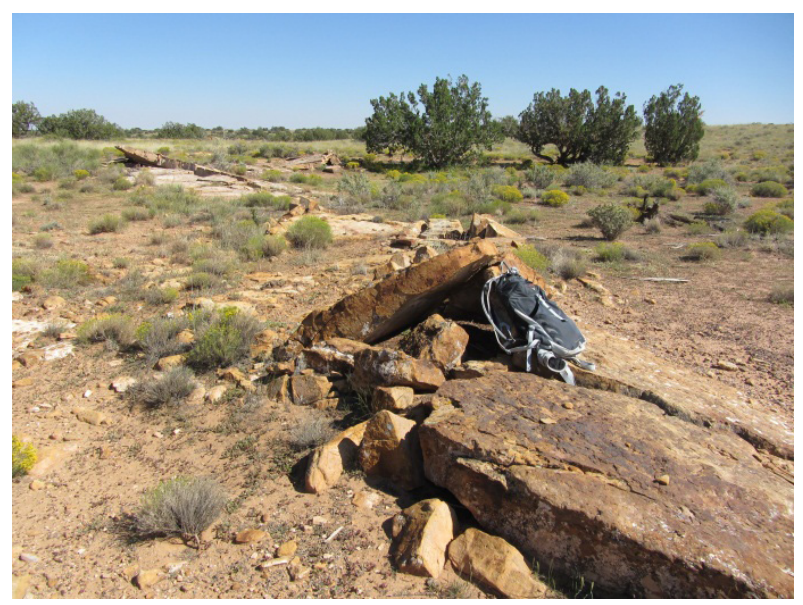

Figure 5. Example of a compression ridge within the eastern subsidence feature. Broken bedrock along this ridge follows a sinuous east-west trend. Bedrock slabs in the background are pushed against and above one another.

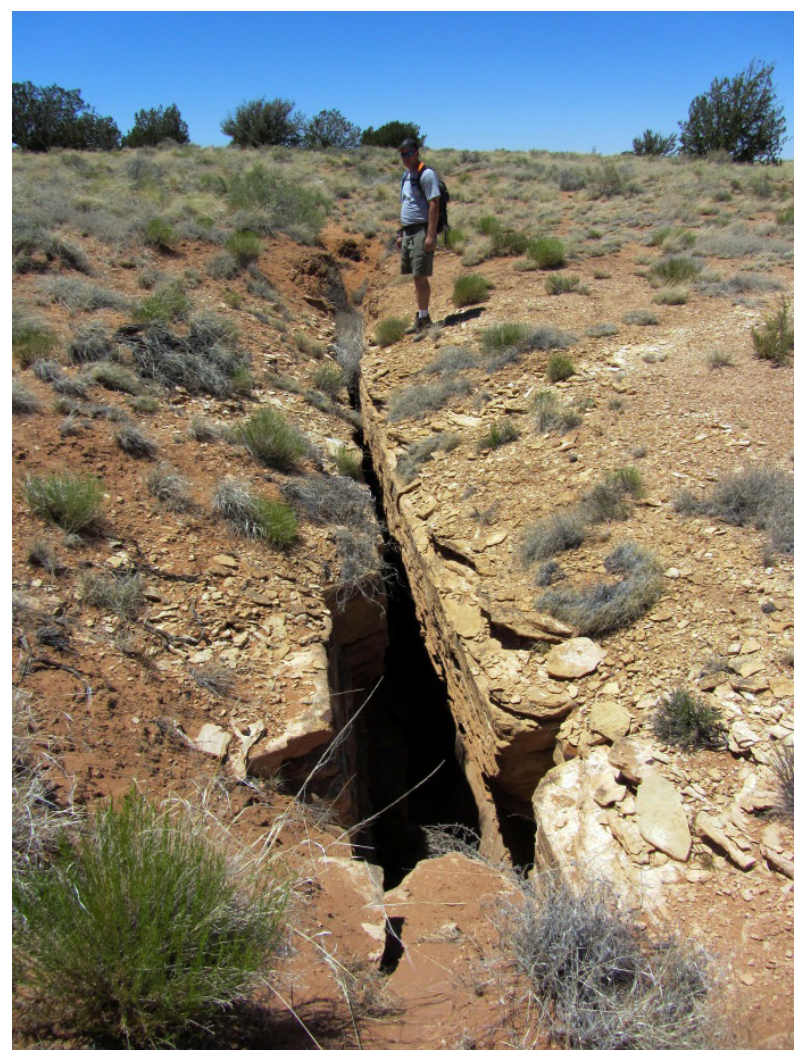

Figure 6. Example of an expanded joint within the eastern subsidence feature.

\section{Active Sink Morphology}

The thickness of salt below the western and northern subsidence features is approximately $30 \mathrm{~m}$ at a depth of approximately $240 \mathrm{~m}$ and $225 \mathrm{~m}$, respectively. Salt below the eastern subsidence feature is between 30 

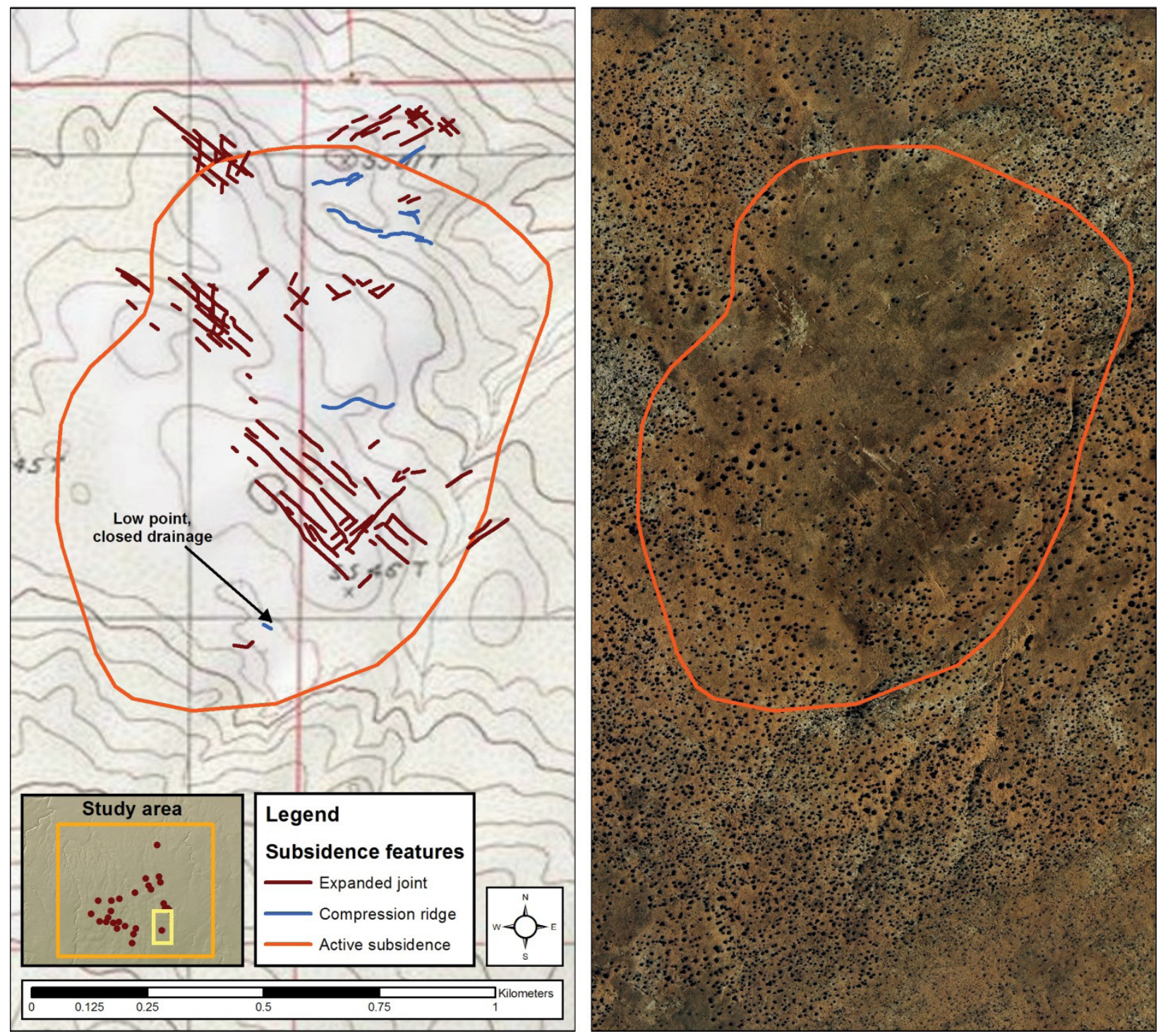

Figure 7. Subsidence-related geomorphic features of the eastern active sink. Aerial imagery from 2010 National Agricultural Imagery Program (NAIP).

and $60 \mathrm{~m}$ thick at a depth of $245 \mathrm{~m}$. For comparison, salt below the greatest concentration of evaporitekarst features along the Holbrook anticline is between 60 and $90 \mathrm{~m}$ thick at a depth of approximately $230 \mathrm{~m}$ (Rauzi, 2000). The eastern sink was visited in the field and subsidence-induced geomorphic features such as drainage reversals, closed-basin formation, compression ridges, and expanded joints were observed (Figure 7).

The overall shape of the eastern sink is that of a broad depression with gently sloping sides that gradually rise to meet undeformed subtly northeast-dipping beds of Coconino and Moenkopi sandstone outside the InSAR signature. While no vertical walls or steep sides are present at the eastern sink as observed in more mature, inactive sinks nearer the Holbrook anticline, the deepest portion of the eastern sink near the southern portion of InSAR signature is adjacent to a distinct Coconino Sandstone slope with many expanded joints. Similar exposures exist near the northern and northwestern limits of the actively subsiding sink. The depth of the eastern sink reaches a maximum of approximately 13 $\mathrm{m}$ relative to the top of surrounding sandstone slopes which is dramatically less than depths observed at many mature, inactive sinks to the west.

Drainages near the southern limit of the eastern sink terminate in a fine-grained, sediment-filled bowl 
surrounded by juniper and small shrubs. Slabs of broken Coconino Sandstone litter the slopes. Portions of drainages in the subsiding area that previously flowed northeast now flow southwest into the closed depression. No water was present in the lowest point during any of our field visits, so it is unknown whether standing water develops or flow infiltrates immediately during heavy runoff events.

No standing-water lines or flotsam rings were observed. Rills, bar and swale channel deposits, and plant matter suspended in and around trees near channels indicate at least moderate overland flow has occurred recently in channels leading to the lowest point of the sink.

Fine-grained reddish sand, presumably reworked from nearby Moenkopi outcrops, mantles much of the side slopes and bottom of the active sink. Occasionally this nearly continuous cover is broken by collapse of the overlying sediment into an open joint below (Figure 6). These open joints are typically 20-30 cm wide and up to several meters deep. Joint width tapers with increasing depth, and the bottoms of open joints are filled with red sand that has fallen in from above. Linear depressions in surface sands often parallel or lead to exposed joints. There are likely many more open joints in the shallow subsurface that are presently obscured or plugged by overlying sand. Areas of exposed bedrock within the subsidence feature exhibit broken rock along expanded joints and are generally open to greater depths than those mantled by sediment. The Coconino Sandstone has two joint orientations that are alternately expanded depending on orientation relative to tension from ongoing subsidence. In some locations within the subsiding area joint orientations are alternately expanded resulting in a zig-zag openjoint set appearance. Exposed Coconino Sandstone at the northern and northwestern edge of the InSAR signature exhibits wide expansion joints up to $1 \mathrm{~m}$ across, up to $10 \mathrm{~m}$ deep, with vertical offset up to $1 \mathrm{~m}$ between blocks. Successive vertical offset across open joints has resulted in a topographic slope defining the edge of the active subsidence feature. Coconino outcrops beyond these exposures do not exhibit this deformation. The presence of wide expansion joints with vertical offset just beyond the limits of modern subsidence indicates subsidence may have initiated somewhat farther to the north than indicated by recent InSAR data (Figure 7).
Expansion of joints farther upslope in the subsidence feature results in compression between subsiding blocks lower in the landscape. Compressional ridges have been observed at other subsidence locales in the Holbrook Basin such as the McCauley Sinks, Richard Lake, and at the base of the Holbrook anticline (Neal et al., 1998). The ridges observed here are somewhat smaller than those described by Neal and others but some appear freshly broken, exhibiting jagged broken sandstone shards and slabs of rock precariously balanced against one another (Figure 5). The ridges observed in the eastern active sink are 1-2 m tall, several meters wide, and up to 200 $\mathrm{m}$ long. The ridges trend roughly east-west and are more abundant in the northern portion of the subsidence feature immediately downslope from the cluster of wide expanded joints with vertical offset at the northern limit of modern subsidence.

\section{InSAR Methodology}

The ALOS-1 and ERS-1/ERS-2 satellites that were used for the InSAR analysis of the Holbrook Basin utilize sensors of different wavelengths, L-band and C-band, respectively. L-band has a wavelength of approximately $23 \mathrm{~cm}$ while C-band has a wavelength of $5.6 \mathrm{~cm}$. Both sensors are processed using the same interferometric methodology.

Interferometry is used to process the change in phase between each pair of satellite data. It is important to note the C-band and L-band InSAR datasets cannot be processed together due to the different sensors. InSAR processing also requires a digital-elevation model (DEM) to remove the topography from the phase component of the radar signal. A $30 \mathrm{~m}$ DEM from the United States Geological Survey National Map Viewer website (http://viewer.nationalmap.gov/viewer/) was used to remove the topographic phase component.

Both the L-band and C-band interferograms (Figures 2-4) were unwrapped using a color wrap of $1 / 2$ of each sensor's wavelength. When examining the different interferograms, one complete color cycle (blue-redyellow-green-blue) represents $2.8 \mathrm{~cm}$ of deformation for C-band and $12 \mathrm{~cm}$ for L-band. The color bands can be viewed as deformation contours when examining each feature. ADWR recently started collecting regularly scheduled InSAR data (Figure 8) for the Holbrook Basin using the Radarsat-2 C-band satellite. These new InSAR data will provide ADWR with a critical tool for 
monitoring ongoing land subsidence at these two new sinks as well as possible land subsidence associated with planned potash mining around the Petrified Forest National Park.

\section{Conclusions}

Evaporite-karst processes in the Holbrook Basin have created a dynamic, geomorphically intriguing landscape. With recent interest in potash mining and continued storage of liquefied petroleum gas in the same salt body that is the source of dissolution beneath hundreds of nearby evaporite-karst features, understanding modern subsidence rates and mechanisms is important. Because the vast majority of existing evaporite-karst features in the Holbrook Basin are no longer subsiding today, the opportunity to observe the gradual processes that lead to sinkhole formation is an exciting prospect.

In addition to continued subsidence monitoring with InSAR, we have begun collecting repeat field observations, photos, and have installed eye bolts across expanded joints near the edges of the subsidence feature to enable repeat measurement in the future. A benchmark near the most rapidly subsiding area within the eastern sink was installed and static GPS measurements were obtained to supplement future InSAR data and enable repeat surveying of subsidence within the feature. In an attempt to better understand the subsurface geometry

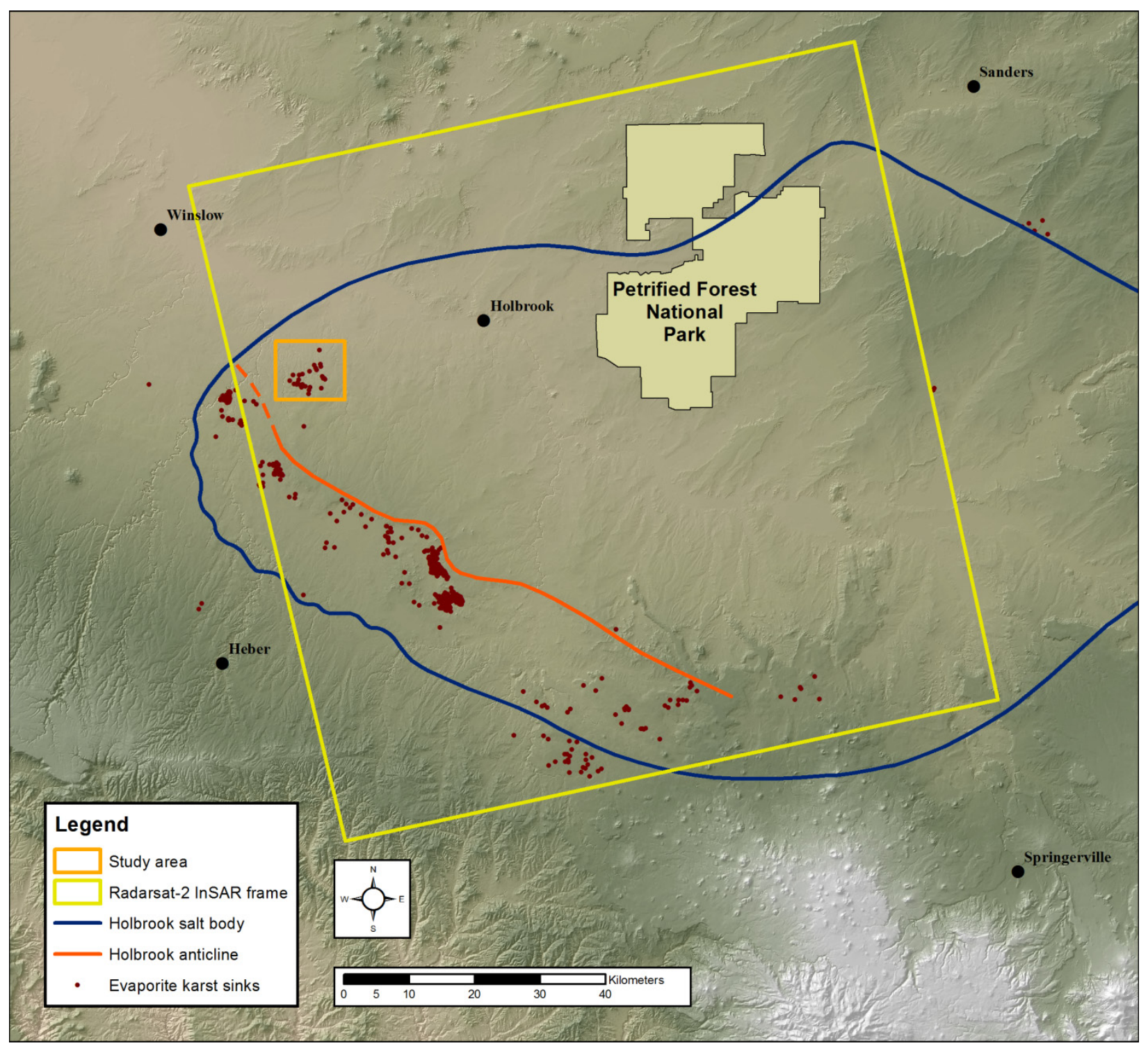

Figure 8. Radarsat-2 InSAR frame used to monitor future land subsidence in the Holbrook Basin. 
and lithologic structure deep Refraction Microtremor (ReMi) and electrical-resistivity measurements were conducted both within and outside the subsidence feature. Results of this investigation are pending and future visits to the eastern subsidence feature to collect tensiometer measurements are planned. In addition, field visits to other nearby active-subsidence features, as well as Richard Lake which most closely resembles the extent and morphology of the eastern active sink, are proposed.

\section{References}

Galloway DL, Hoffmann J. 2007. The application of satellite differential SAR interferometryderived ground displacements in hydrogeology. Hydrogeology Journal 15(1): 133-154.

Neal JT, Colpitts R, Johnson KS. 1998. Evaporite karst in the Holbrook Basin, Arizona. In: Borchers JW, editor. Land Subsidence, Case Studies and Current Research. Belmont (CA): Star Publishing Co. p. 373-384.

Peirce HW, Gerrard TA. 1966. Evaporite deposits of the Permian Holbrook Basin, Arizona. In: Second Symposium on Salt, v. 1. Cleveland $(\mathrm{OH})$ : Northern Ohio Geological Society. p. 1-10.

Rauzi SL. 2000. Permian salt in the Holbrook Basin, Arizona. Arizona Geological Survey Open File Report 00-03. 